\title{
Use of Social Media in Marketing Library Resources and Services
}

\author{
Fortunata Francis Kirita \\ National Institute of Medical Research (NIMR) \\ Email: lovependo00@gmail.com
}

Kelefa Mwantimwa

Information Studies Unit, University of Dar es Salaam

Email: mwantimwa@udsm.ac.tz

\begin{abstract}
This study has investigated the use of social media in marketing library resources and services at MUHAS and SUA. A mixed research approach was used to process, collect and analyse data in the study. While some library staff and all users were conveniently selected, key informants were purposively selected. The data were mainly collected through survey methods. The qualitative data collected were subjected to content analysis while quantitative data were analysed using SPSS. The study's findings suggest that Facebook is the effectively used platform by both the studied libraries in the marketing of library services and resources due to its popularity and convenience. The other effectively used media is WhatsApp, although this was noted only at MUHAS. However, notwithstanding this, the media's usage to market library resources and services has been found generally ineffective. This has been attributed to different challenges such as lack of a written policy for social media usage, unreliable internet connectivity, low promotion, content obsoleteness, and inadequate computer facilities. The study recommends that social media policies should be formulated, investment in ICT infrastructure development should be made, and promotion of social media usage among information users should be done.
\end{abstract}

Keywords: Use, ICT, social media, marketing library resources and services, academic libraries

https://dx.doi.org/10.4314/udslj.v16i2.3

\section{Introduction}

For a long time ago, libraries around the world have been marketing their resources and services using different approaches with the intention of enhancing their access and use (Edewor, 2016; Noel \& Waugh, 2002; Jeremia, 2017). These approaches have undergone various changes as a result of the advent of continuous changes in Information and Communication Technologies (ICTs) (Eligi \& Mwantimwa, 2017). Through their influence on marketing approaches, ICTs have enhanced the marketing of library resources and services allowing both libraries and librarians to justify their existence and demands for more financial resources (Kavulya, 2004). The promotion of library and information resources and services creates awareness among users and enhances their usage and participation in collection development (Alkindi \& Suqri, 2013).

In recent years, librarians and libraries in both developing and developed countries have continued integrating various social media in their promotion of library and information resources and services. In the United States, for example, the majority of libraries and 
information centres use social media platforms to market their library services. For example, South Carolina State Library (SCSL) has integrated a number of social media tools in service provision such as Facebook, Twitter, Blogging, YouTube, Flickr, Google Docs and Wikis (Landis, 2010). Similarly, academic libraries in China are adopting and applying social media to support library and information services. Luo, Wang and Hang (2013) found video series (e.g. Youku) as the most preferred social tools for information and knowledge sharing.

Accordingly, academic libraries in African countries such as South Africa and Nigeria are effectively adopting and using social media to support library resources and services marketing (Ezeani \& Igwesi, 2012). On this, Bosch (2009) reports that libraries in South Africa have integrated social media (e.g. Facebook, Wikis, Delicious, YouTube and Podcasts) to support service provisions. This is also seen in Kenya where Abok and Kwanya (2016) noted that academic libraries use Facebook, WhatsApp, YouTube and Twitter to facilitate the sharing of information resources, the provision of reference services and professional networks information, and promotion of library services. Likewise, academic libraries in Tanzania are not lagging behind in this regard. This is evident in the libraries' use of web 2.0 technologies to foster their services. While Sokoine University of Agriculture (SUA) Library has adopted Facebook and Twitter, MUHAS uses Facebook, Twitter and blogs to support library and information services and resources (Mwantimwa \& NkhomaWamunza, 2016; Lwoga, 2014).

However, despite the adoption of social media in the library context, low usage of library services and resources in academic libraries is documented in several previous studies (e.g. Alphonce \& Mwantimwa, 2019; Mollel \& Mwantimwa, 2019; Manda, 2005; Mwantimwa et al., 2021). These studies have associated this problem with low awareness of some subscribed online library services and resources (Mwantimwa et al., 2017). Although several studies (e.g. Nduka, 2015; Jeremia, 2017) have been conducted on the marketing of library resources in higher learning institutions in Tanzania, little is known about the usage magnitude and effectiveness of social media platforms. It is against these observations that the present study has been carried with a focus to investigate the use of social media in marketing library resources and services at SUA and MUHAS. Specifically, the study intended to examine the types of social media university libraries use in the marketing of library resources and services; unveil the extent to which social media are effective in enhancing the marketing of library resources and services; and establish reasons for using social media in marketing library resources and services.

\section{Literature review}

\section{Types of social media used in the marketing of library resources and services}

In recent years, the world has witnessed the adoption and use of different types of social media platforms in the marketing of library services and resources. Social media platforms such as Blogs, Facebook, YouTube, Twitter, Myspace, Pinterest, Google Plus, Instagram, Mashup, Flickr, LinkedIn and Wikis are some of those used for this purpose (Abok \& Kwanya, 2016; Mwantimwa \& Nkhoma-Wamunza, 2016; Ezeani \& Igwesi, 2012). Among these, libraries in the US mostly use Facebook to market their collections; for example South Carolina State Library (SCSL) uses this media followed by Twitter in addition to blogging, YouTube, Flickr, Google Docs and Wikis (Landis, 2010). The high usage of this media follows the heavy presence of higher learning students on this media in the USA (Zickuhr, 2010). This state presents library and information professionals with an opportunity to communicate with users and market resources and services to bigger audiences (Kyung-Sun \& Sin-Sei-Ching Joanna, 2014). 
In contrast, Luo, Wang and Hang (2013) found video series (e.g. Youku) as the most important social tools for marketing library services and resources. Furthermore, Khan and Bhatti (2012) assert that online news groups or forums, video sharing (YouTube), social networking (Facebook, MySpace), Wikis, professional networking and blogging are good avenues for marketing library resources and services. These media are used to spread news and service alerts, providing quick services updates to online users and publishing library news and press releases for online users. In all, these social media platforms allow libraries to promote their resources and services.

\section{Effectiveness in social media usage to market library resources and services}

Literature (e.g., Kyung-Sun \& Sin-Sei-Ching, 2014; Ezeani \& Igwesi, 2012; Deng, Zhang \& Xu, 2016; Luo, Wang \& Han, 2013) shows that many librarians and information professionals in libraries and information centres actively use social media to promote library services and resources. Among the social media platforms effectively used for this purpose in the US and Singapore is YouTube. Similarly, students of various universities have been reported to heavily use Facebook to access library and information services (Zickuhr, 2010). Noting from Nigeria, social media sites such as Facebook, MySpace, Flickr, YouTube, Library thing, and Ning are important and effective in the promotion of library and information services (Ezeani \& Igwesi, 2012). Among these platforms, Deng et al. (2016) reveal that Facebook is the most popular. In contrast, Nduka (2015) reported that social media are ineffectively used to promote library services and resources because the majority of the students were unaware of its wider applications for educational purposes. In support of this a study by Alphonce and Mwantimwa (2019) found that students used social media mostly for social purposes as opposed to education.

In fact, the effectiveness of social media in supporting library information services provision varies across individual libraries across the globe. For example, academic libraries in the US and China effectively use different social media apps such as We Chat, Facebook, Twitter, Weibo and blogs for this purpose (Deng, Zhang \& Xu, 2016). Similarly, a study by Abok and Kwanya (2014) reported that Facebook, Twitter, Instagram and LinkedIn were the most popular and effective in this respect. The study disclosed that 58 percent of libraries in Kenya used Facebook on regular basis while 46 percent of them used Twitter and 30 percent used blogs. Other platforms effectively used for this purpose include Google+, Instagram, Pinterest, Flickr, Academia.edu and Research Gate. Mundt (2013) carried out a survey among German public and academic libraries to evaluate the marketing success of libraries' social media presence. The findings revealed that Facebook is particularly effectively used in marketing library resources. Also, Chu and Du (2013) investigated the use of social media in academic libraries, library staff perceptions of their usefulness and challenges faced in doing so. Like in other empirical studies, it was found that Facebook and Twitter were the most effective tools.

\section{Reasons for using social media to market library resources and services}

Reasons for libraries' adoption and use of social media vary from one environment to another. One of the main reasons is that social media are free and allow users to easily create personal pages filled with content in the form of images, music, and videos. The social have a vast number of users hence attracting academic libraries with the opportunity of connecting them with their user communities (Jain, 2013; Kong, Chiu \& Ho, 2016; Bosch, 2009. In 
addition, social media allows librarians and other information professional to communicate and share information with users and provide services to them (Kong, Chiu \& Ho, 2016; Mwantimwa \& Nkhoma-Wamunza, 2016; Nduka, 2015; Alisharqi, Hashim \& Kutbi, 2015). Besides that, social media has increasingly become an integral part of library and information professionals' lives worldwide and have revolutionised communication, marketing of library resources and services, and information sharing. In fact, in their diversity, social media platforms serve as avenue for news, announcements and social interaction among library staff and users (Deng et al., 2016; Ezeani \& Igwesi, 2012; Kong, Chiu, \& Ho, 2016; Abok \& Kwanya, 2014; Hashim et al., 2016). Findings from a study by $\mathrm{Chu}$ and $\mathrm{Du}$ (2013) reveal that social media were used to accelerate interactions between librarians and students. In other words, libraries' social media usage helps libraries to keep their image alive in the minds of user communities.

Apart from that, Khan and Bhatti (2012) contend that social media normally allow libraries to capture the attention of online users and advertise their resources and services to them and foster knowledge sharing. According to Nduka (2015), the use of social media to market library resources and services saves time, is cost effective, exciting, stimulates users, and facilitates access to and use of library resources and services. The media also facilitate instant information dissemination to communities in a creative manner and allow library staff to reach more users. In addition, these media give users an opportunity to ask questions and get prompt answers from the library staff (Alphonce \& Mwantimwa, 2019). In this regard, Landis (2007) asserts that the use of social media in marketing library resources and services saves time and money while allowing libraries to easily reach users. Likewise, Abok and Kwanya (2014) insist that social media tools provide librarians and libraries with the capacity to engage users in multi-directional communication while promoting library services and resources beyond geographical boundaries and physical library buildings.

\section{Literature gap}

The literature reviewed reveals that much has been written on the adoption and use of social media to market library services. In fact, various studies have covered the use of social media (Landis, 2007; Nduka, Ezeani, \& Igwes, 2015) while a few (e.g. Burkhardt, 2010) have covered the usage of social media to market library resources and services. In contrast, studies carried out in Tanzania (e.g. Mwantimwa \& Khoma-Wamunza, 2016; Lwoga, 2014) have examined the integration of web 2.0 technologies in library services provision in university libraries. In other words, there are hardly any studies that have examined how effectively social media is being usage to market library resources and services in Tanzanian libraries. As such, this study set out to fill this gap.

\section{Research design and methods}

This study used descriptive research design which combined qualitative and quantitative approaches. The use of a mixed research approach increases the credibility and reliability of the data. This entails that the study has benefited from the strengths of both the approaches. In a mixed research approach, a researcher chooses to combine different types of research designs deemed suitable for addressing research questions. In this case, the study can produce a combination of statistical and experiential data. The quantitative approach was instrumental in gaining insights pertaining to the frequency and trends of social media usage, types of social media used, and reasons for using the media. On the other hand, the use of qualitative approach was necessary so as to answer questions that could otherwise not have been answered quantitatively. In addition, the use of this method helped to offset the weakness of the quantitative approach. In fact, the approach was considered appropriate for 
exploring the perceptions, opinions, and attitudes towards the use of social media in marketing library resources and services.

The study was conducted at the libraries of the Muhimbili University of Health and Allied Sciences (MUHAS) in Dar es Salaam and Sokoine University of Agriculture (SUA) in Morogoro region. The libraries were chosen because they use social media to market their services and resources. These academic libraries are among those that have integrated ICTs in their operations and service provision. Specifically, the two libraries have integrated web services to support the promotion, dissemination and sharing of information among librarians and patrons. More significantly, the two libraries have formalised the use of social media to support the promotion of services resources, and dissemination and sharing of information and knowledge to enhance the accessibility and usability of library and information resources and services.

The population of this study included librarians, students and academicians. Librarians were involved because they market library resources whereas students and academicians are the users of the marketed library resources and services. In all, 105 respondents (64 students, 26 academic staff and 15 library staff) participated in the study. Among these, 59 were drawn from SUA and 46 from MUHAS. The respondents were selected mainly using convenience and purposive sampling. Purposive sampling is a technique that allows a researcher to select a sample on the basis of his or her knowledge of the study population and its elements, and in accordance with specific research aims. It is based on a researcher's judgment and the purpose of the study (Babbie, 2011). Whereas other library staff and library users (students and academicians) were selected conveniently, library directors were purposively selected. These respondents were selected because they were expected to provide valuable information on the effectiveness of using social media in marketing library resources and services in their universities.

Regarding data, both secondary and primary data were collected using different methods. According to Aina (2002), the choice of research methods depends on the purpose of the research and the research questions being asked. This study used multiple data collection methods. The use of multiple methods tends to minimise the degree of specificity of certain methods of particular bodies of knowledge, allows for the triangulation of data collection tools, and enhances the validity and reliability of findings. To capture such attributes in this study, cross-sectional structured questionnaires were employed and supplemented by in-depth interviews and analysis of documentary sources.

During data analysis, various methods were used to code, organise and summarise data collected from the field. Both qualitative and quantitative data were processed and analysed in line with the objectives of the study. The qualitative data collected from interview sessions were transcribed and then subjected to content and thematic analyses. Accordingly, the quantitative data was coded, organised and analysed using the Statistical Product and Service Solutions (SPSS) version 16 to derive descriptive statistics such as frequencies, percentages which have been presented in tables and charts. The frequency and percentages are important in establishing trends and extent of social media application.

\section{Results and interpretation}

\section{Socio-demographic characteristics of the respondents}

The study collected personal information of respondents so as to categorise them by the institutions they worked for, gender, age, level of education, level of study, position and 
work experience. Demographic characteristics are vital in understanding service provision and usage. Descriptive statistics (e.g. frequencies and percentages) were derived from the available data to compare various categories of the variables as Table 1 summarises:

Table 1: Socio-demographic characteristics

\begin{tabular}{|c|c|c|c|}
\hline Socio-demographic $(\mathrm{n}=105)$ & & Frequency & $\%$ \\
\hline \multirow[t]{2}{*}{ Institution [n = 105] } & SUA & 59 & 56.2 \\
\hline & MUHAS & 46 & 43.8 \\
\hline \multirow[t]{2}{*}{ Gender $[n=105]$} & Female & 37 & 35.2 \\
\hline & Male & 68 & 64.8 \\
\hline \multirow[t]{5}{*}{ Age $[n=105]$} & Below 20 & 1 & 1.0 \\
\hline & $20-29$ & 64 & 61 \\
\hline & $30-39$ & 24 & 22.9 \\
\hline & $40-49$ & 13 & 12.4 \\
\hline & $50+$ & 3 & 2.9 \\
\hline \multirow[t]{5}{*}{ Level of education $[n=41]$} & Diploma & 9 & 22 \\
\hline & Bachelor & 5 & 12 \\
\hline & Masters & 17 & 41 \\
\hline & $\mathrm{PhD}$ & 7 & 17.4 \\
\hline & Not use & 3 & 7.2 \\
\hline \multirow{2}{*}{ Students' level of study $[n=64]$} & Undergraduate & 54 & 84.3 \\
\hline & Postgraduate & 10 & 15.6 \\
\hline \multirow{3}{*}{ Status of respondents $[n=105]$} & Academic staff & 26 & 24.8 \\
\hline & Students & 64 & 61 \\
\hline & Library staff & 15 & 14.3 \\
\hline \multirow[t]{5}{*}{ Position of library staff $[n=15]$} & Senior librarian & 3 & 20 \\
\hline & Principal librarian & 2 & 13.3 \\
\hline & Assistant librarian & 5 & 33.3 \\
\hline & Library assistant & 4 & 26.7 \\
\hline & Library officer & 1 & 6.7 \\
\hline \multirow[t]{5}{*}{ Experience of library staff $(n=15)$} & $0-5$ years & 6 & 40 \\
\hline & $6-10$ years & 5 & 33.3 \\
\hline & $11-15$ years & 2 & 13.3 \\
\hline & $16-20$ years & 1 & 6.7 \\
\hline & $20+$ years & 1 & 6.7 \\
\hline
\end{tabular}

This findings entail that most $(56.2 \%)$ of the respondents were from SUA. Comparing the two universities, SUA has a bigger population of students and staff than MUHAS. This can be attributed to the fact SUA has more academic departments. Regarding gender, the results show that more than three fifths $(65 \%)$ of the respondents were males whereas 35 percent were females. This implies that the majority of the respondents were males. Agewise, the findings indicate that most $(61 \%)$ of the respondents were aged between 20 and 29 . This is an understandable fact considering that students made a significant percentage of the respondents. The findings further indicate that staff members were holders of diplomas, bachelors, masters and PhDs. In fact, majority of academic staff held master's degrees, followed by those with PhDs and bachelor's degrees. This trend is not the same for library staff, as most of them held either a diploma or a bachelor's degree. 
Besides, the findings show that a significant percentage $(84.3 \%)$ of the students that participated in the study were undergraduates. This is associated with the fact that the enrolment of undergraduate students is higher than that of postgraduate students. Another explanatory factor is that higher educational loans from Higher Education Students Loans Board (HESLB) are more accessible to undergraduates than postgraduates as affirmed by Eligi (2015). Along that, the findings show that majority $(61 \%)$ of the respondents were students. This category was followed by academic staff $(25 \%)$ and library staff $(14 \%)$. The big presence of students in the sample is a result of their domination of university populations. This extent of students' presence in the sample has not negatively affected the results being presented because their presence was good for measuring the use of social media to market library resources and services.

Regarding library staff's positions, the findings suggest that around a third (33\%) of library staff are assistant librarians while $27 \%$ were library assistants. The findings further indicate that a few of the staff were senior librarians, principal librarians while one was a library officer. This is associated with the fact that only a few librarians reach the level of senior and principal librarians. With regard to the working experience, the results show that $40 \%$ the library staff had been in this line of work for less than five years whereas $33 \%$ were in it for a period between 6-10 years. Furthermore, the findings suggest that very few of them had work experiences of 11 to 20 years while other had over 20 years of experience.

\section{Pathways to awareness of library resources and services}

The study sought to establish how respondents became aware of library resources and services. This was done to establish how awareness about resources and services is raised by the libraries studied so as to identify the channels used and the frequency of their use. Table 2 presents the outputs generated from the data collected:

Table 2: Ways of becoming aware of library resources and services

\begin{tabular}{lccc}
\hline Ways (n= 90) & Frequently & Occasionally & Never \\
\hline Colleagues & $30(33.3 \%)$ & $33(36.6 \%)$ & $27(29.9 \%)$ \\
General meeting & $6(6.6 \%)$ & $15(16.6 \%)$ & $69(77.0 \%)$ \\
Text messaging & $15(16.6 \%)$ & $18(20.0 \%)$ & $57(63.3 \%)$ \\
Mails & $11(12.2 \%)$ & $21(23.3 \%)$ & $58(64.4 \%)$ \\
Websites & $56(62.2 \%)$ & $18(20.0 \%)$ & $16(17.7 \%)$ \\
Notice boards & $35(38.8 \%)$ & $24(26.6 \%)$ & $31(34.3 \%)$ \\
Social media & $33(36.6 \%)$ & $22(24.4 \%)$ & $35(38.8 \%)$ \\
\hline
\end{tabular}

In general, the findings reveal that various channels are used to raise awareness about library resources and services. Specifically, the majority of library users involved in the study are made aware of the services and resources through websites (82.2\%) and social media (61\%) platforms. This suggests that institutional websites are the most used channels to promote services and resources. This avenue publicly portrays the profile of an institution, including library resources and services available. The findings also indicate that noticeboards are highly used to raise awareness on the library resources and services as cited by $65.4 \%$ of users. Evidently, during the fieldwork, the researcher observed the presence of noticeboards in different locations of the studied universities. Furthermore, the findings affirm that oral communication is one of the important means of sharing information on library resources and services as proven by $69.9 \%$ and $23.2 \%$ of respondents who identified colleagues and 
meetings as their source of information about resources and services respectively. One of the key informants responded to a question on this as following:

We have a WhatsApp group for academic staff through which the library director shares information with other colleagues on newly-acquired library resources. This group is frequently used to disseminate information and promote library services and resources. WhatsApp is an important platform for promoting and sharing information on library services and resources faster and conveniently. Assurance of reaching large population of academic staff is higher when using this channel.

The narration confirms the use of social media to promote library services and resources at the two librarians studied. Noting from the quotation, social media appears to be viewed as a very important platform for marketing library resources and services.

\section{Use of social media in marketing of library resources and services}

Under this section, results on library staff's use of social media to market services and resources are presented. The results show that $12(80 \%)$ of the respondents agreed that they use the media to market their services and resources while three $(20 \%)$ said they do not. The results suggest that the media are used by the majority of library staff for this purpose. Along this, the study also sought to determine the types of social media the staff use to market library services and resources. The data outputs generated are shown in Table 3:

Table 3: Social media used to market library services and resources

\begin{tabular}{lcc}
\hline Social media & Frequency & Percent \\
\hline Facebook & 77 & 73.3 \\
WhatsApp & 34 & 32.4 \\
Twitter & 32 & 30.5 \\
You Tube & 19 & 18.0 \\
Instagram & 14 & 13.3 \\
Blogs & 11 & 10.5 \\
\hline
\end{tabular}

The findings reveal that a significant percentage (73.3\%) of library staff cited Facebook as the most used platform to market library resources and services. Similarly, during interview sessions, one key informant informed that "Facebook is preferred by the majority of users due to its popularity and convenience of use". Moreover, the findings portend that WhatsApp and Twitter were moderately deployed in the marketing of library services and resources. Overall, these findings show that SUA has adopted and uses Facebook, WhatsApp, YouTube, and SUA TV (an online TV) whereas MUHAS largely uses Facebook and WhatsApp. Regarding WhatsApp, one key informant testified that:

It is apparent that WhatsApp is increasingly becoming a popular social media in the promotion of products and services. This follows rapid ICT developments that have seen the birth and popularity of devices such as smartphones, tablets and other electronic gadgets that foster the deployment of social media such as WhatsApp and Facebook in marketing. A large portion of students and academic staff have smartphones.

Accordingly, one of the respondents interviewed said: 
We select some few social media such as Facebook, WhatsApp, YouTube, LinkedIn and ResearchGate based on their popularity, relevance and appropriateness. We also we consider the media that attract a significant number of our users, especially youths and young adults who are eager to deploy social media.

Furthermore, another respondent asserted that:

Instagram, YouTube, Google and Blogs are some of the popular social media but they are still not used for promoting library resources and service. Instagram is popular but it is not appropriate for academic purposes, particularly in library and information science. Instagram is not designed for educational purposes; however, librarians could innovatively find a way to effectively use it to market and promote library resources and services so as to take advantage of the presence of a large number of users on it. Popularity, relevance and appropriateness are important determinants of decisions to adopt and apply social media in library settings.

These narrations entail that the adoption and application of social media depend on different factors. Evidently, popularity, relevance, and appropriateness are important factors in this regard. Along these, usefulness, ease-of-use and positive attitudes of individual library users and librarians are important. On the other hand, the study has found that some social media platforms mentioned by the librarians were insignificantly used to promote library resources and services.

\section{Effectiveness of social media in marketing library resources and services}

The study also had questions that sought to establish the level of effectiveness of social media usage in the promotion of library services and resources. The questions were important in establishing an understanding on the kinds of social media effectively used for this purpose. To gauge effectiveness of social media in marketing library resources and services, an ordinal scale (i.e. $1=$ Very effective, $2=$ Effective, $3=$ Ineffective) was used as the results in Table 4 show:

Table 4: Effectiveness of social media in marketing library resources and services

\begin{tabular}{lccc}
\hline Social media & Very effective & Effective & Ineffective \\
\hline Facebook & $52(49.5 \%)$ & $23(21.9 \%)$ & $33(31.4 \%)$ \\
WhatsApp & $24(22.9 \%)$ & $19(18.1 \%)$ & $62(59.0 \%)$ \\
Twitter & $26(24.8 \%)$ & $38(36.2 \%)$ & $41(39.0 \%)$ \\
You Tube & $11(10.5 \%)$ & $22(20.9 \%)$ & $72(68.6 \%)$ \\
Instagram & $9(8.6 \%)$ & $19(18.1 \%)$ & $77(73.3 \%)$ \\
Blogs & $10(9.5 \%)$ & $28(26.7 \%)$ & $67(63.8 \%)$ \\
\hline
\end{tabular}

The results in Table 4 show that majority $(71.4 \%)$ of respondents cited Facebook as the most effectively used media followed by Twitter (61.0\%) and WhatsApp (41.0\%). Blogs appear to be the least effectively used. The reasons for effectiveness use of Facebook, Twitter and WhatsApp were provided by some of key informants during interview sessions. For example, the findings show that availability of relevant policies fosters the usage of social media in the two libraries. On this, a key informant at SNAL said: 
We have policies such as library development policy; SNAL collection development; repository policy and SUA ICT policy. These policies place particular emphasis on the dissemination of information and library services through different media to increase awareness about and visibility of library materials.

This quotation shows that the libraries surveyed have policies and operational procedures in place which indirectly guide their usage of electronic systems such as social media. However, the findings show ineffective usage of the media to market resources and services as evident in the limited sharing of information through the media. One of the key informants interviewed shared this on this matter:

Information posted on the Facebook does not reflect library services and resources available. Facebook is frequently used to announce workshops. These announcements are generally on the records management and organisation of knowledge workshops for professionals and not those aimed at promoting resources and services.

Ineffectiveness use of social media was noted in users' limited awareness about the media platforms that are used to market library services and resources as one key informant narrated:

A large segment of our students are not aware of the kinds of social media used to promote library services and resources. This works against us in addition to the irrelevance to our marketing cause of the information posted on these platforms. There is inadequate provision of instructions on how to use social media platforms to access information related to library resources and services.

This testimony suggests that library users' low awareness about social media platforms used to market services and resources undermines effective usage of social media to market library resources and services. Therefore, despite the heavy usage of social media among university students, the media appear to be inadequately used to inform them about library services and resources as confirmed by their complaints about limited promotion. Adding to these, another key informant narrated that:

Social media are not effectively used to market library resources and services. Factors such as unreliable internet connection, low bandwidth, obsolete of contents, inadequate computers and lack of online reference librarians limit effectiveness in the use of this media for this purpose.

This entails that information services and resources' promotion and marketing through social media remains largely unsatisfactory, which obvious leads to their underutilisation. Library users associated this problem with low priority of social media usage in marketing library services and resources. However, observations made oppose these findings from library staff interview data. Contrary to what was learned through interviews, ICT facilities such computers did not seem like a big problems at the moment data were collected. In addition, most students had smartphones through which social media is accessible. Nevertheless, the findings suggest that social media is ineffectively used to market library resources and services and this is a result of various factors.

\section{Reasons for using social media in marketing library resources and services}


The study also established the reasons for using social media in marketing library resources and services. Respondents were asked to indicate their perceptions on the use of this media on an ordinal scale and their responses have been summarised in Table 5:

Table 5: Reasons for using social media in marketing

\begin{tabular}{|c|c|c|c|}
\hline Reasons for using social media & Agree & Neutral & Disagree \\
\hline Friendliness of social media & $84(80 \%)$ & $11(10.5 \%)$ & $10(9.5 \%)$ \\
\hline Convenience for raising awareness & $76(72.4 \%)$ & $18(17.1 \%)$ & $11(10.5 \%)$ \\
\hline Effective information $\mathrm{d}$ & $72(68$. & $17(16$ & $16(15.2 \%)$ \\
\hline Ease of use & $80(76.2 \%)$ & $8(7.6 \%)$ & $17(16.2 \%)$ \\
\hline $\begin{array}{l}\text { Easy reaching of larger numbers of libr. } \\
\text { users }\end{array}$ & $77(73.3 \%)$ & $9(8.6 \%)$ & $19(18.1 \%)$ \\
\hline Facilitates knowledge sharing & $70(66.7 \%)$ & $3(2.9 \%)$ & $32(30.5 \%)$ \\
\hline Facilitates communications & $61(58.1 \%)$ & $14(13.3 \%)$ & $30(28.6 \%)$ \\
\hline They are learning and teaching tools & $64(60.9 \%)$ & $8(7.6 \%)$ & $33(31.4 \%)$ \\
\hline They enable virtual discussions & $47(44.8 \%)$ & $19(18.1 \%)$ & $39(37.1 \%)$ \\
\hline The & $61(58$ & $6(7$ & $38(36.2 \%)$ \\
\hline Allow quick feedbac & $70(66.7 \%)$ & $22(20.9 \%)$ & $13(12.4 \%)$ \\
\hline
\end{tabular}

Generally, the findings in Table 5 suggest that social media's use in marketing library resources and services is propelled by various factors. According to the findings, its userfriendliness is key in the media's use for this purpose as revealed by $80 \%$ of respondents. This factor was is followed by the media's ease of use (76.2\%), ability to reach larger number of library users $(73.3 \%)$, convenience in raising awareness $(72.4 \%)$, effective information dissemination (68.6\%), ability to facilitate knowledge sharing, and quick provision of feedback $(66.7 \%)$. These reasons are closely related to those provided by key informants during interview sessions. For instance, one respondent pointed out that:

Social media such as Facebook and Twitter are increasingly becoming more popular avenues in the library and information settings than conventional means of communication. One logical explanation for their adoption is that they do not require advanced Internet knowledge or experience to use.

The narration informs that the popularity of social media contributes to their importance. According the statistical outputs in Table 5, social media are also used for marketing purposes because they are learning and teaching tools (60.9\%), communication facilitators and enablers multiple access to information (58.1\%), and enablers of virtual discussion (44.8\%). Overall, these findings show that libraries' adoption of these media for marketing purposes can be attributed to the qualities that the media present. 


\section{Discussion}

This study has investigated the use of social media in marketing library resources and services. Among other things, the findings have revealed that Facebook is the platform most used by the studied libraries to market their resources and services. This is as a result of the popularity and convenience of this media although this does not mean that other media such as YouTube and Instagram are not popular and convenient. The findings also clearly inform that Facebook and Twitter have been formally integrated into the libraries' promotion of resources and services. Despite this, Twitter is insufficiently used for this purpose along WhatsApp. As for Instagram, YouTube, Google and Blogs, the libraries are yet to include them in their formal marketing plans. According to the findings, Facebook is the media that is more effectively used by the libraries studied to market library services and resources. These findings are in line with a number of previous ones (Deng et al., 2016; Ezeani \& Igwesi, 2012; Zickuhr, 2010) which document that Facebook was used by many libraries because of its popularity. This is however quite different from what has been noted by Kyung-Sun and Sin-Sei-Ching (2014) that the top three effectively used social media platforms in the academic context in the USA and Singapore were Wikis, Q and A sites and YouTube. Similarly, the findings of this study differ in this respect (effective Facebook usage) from those of other studies (e.g. Mwantimwa \& Khoma-Wamunza, 2016; Nduka, 2015). Nevertheless, there are various other studies (e.g. Deng, 2016; Abok \& Kwanya, 2014; Mundt, 2013) that reported similar findings to this study's. According to Nduka (2015), the application of social media for educational purposes is very limited primarily because students are unaware of its wider applicability for this purpose.

As the findings inform, some social media were ineffectively used to market library service and resources. Based on the findings, these media appear to be less used because of low promotion of their potential role, lack of a written social media policies, and unreliable internet services. These findings are in agreement with some extant studies (e.g. Chu \& Du, 2013; Ezeani \& Igwesi, 2012), which revealed that ineffectiveness of social media was attributed to by low awareness, poor internet connectivity, technophobia, and unreliable power supply. This ineffective usage of these media to market resources explains the surveyed libraries' reliance on traditional ways of communications such as notice-boards and face-to-face conversations to market resources and services. This shows that electronic and print media are simultaneous applied by the surveyed libraries to promote services and resources. This finding concurs with Jeremia's (2017) observation that notice-boards and posters were commonly used at SUA to promote library resources and services.

Aside from that, the findings have established different reasons behind the studied libraries' use of social media to market library services and resources. The ability of social media to foster networking, communication, information dissemination and knowledge sharing has made it attractive to the libraries in question. In addition, social media such as Facebook and WhatsApp are user-friendly, convenient, and have wide coverage. Like other electronic applications, social media facilitate multiple accesses to services and resources. Similarly, Khan and Bhatti (2012) agree that social media platforms such as Facebook, MySpace and YouTube are good venues where marketing of libraries' resources and services can be done in addition to institutional websites. These media are important tools for spreading news and service alerts, providing quick updates to online users and publishing library news and press releases for online users.

\section{Study implications}


The findings of this study can awake other libraries interest in using web resources such as social media to support marketing of services and resources. In all, the study findings are important and provide planners and policy-makers in the Ministry of Education, Science and Technology (MoEST), higher learning institutions with baseline information for formulating plans, policies, strategies, and reforms regarding the integration of social media in academic libraries. Library professionals will be able to rethink their ways of using social media to enhance library services provisions through the findings of this study. Moreover, the study is likely to enhance awareness among university libraries in Tanzania on the importance of social media in marketing library services. Besides, the study's findings contribute to the existing knowledge in the literature on marketing of library resources and services in academic libraries.

\section{Study limitations}

This study mainly deployed convenience sampling. The use of this sampling technique has limited the generalisation of the study's findings. As such, a study to extensively explore the application of social in library services promotion is still needed. Apart from that there is a need for conducting a study to examine the current state of service automation in Tanzania's academic libraries and the integration web 2.0 technologies including social media. Also, further research should be conducted to assess the impact of including social media in library service provision.

\section{Conclusion and Recommendations}

Social media are important as they enhance library service provision and ensure effective resource usage. Moreover, the media strengthen communications and the dissemination of information through allowing quick responses to information queries. The media also improve current awareness services and simplify information access and use. Furthermore, proper use of social media ensures effective time management in the collection, organisation and management of library operations. The study has identified several challenges facing the selected academic libraries' usage of social media to promote resources and services and based on them, the following recommendations are put forward: It is also important for the two libraries studied to formulate social media usage policies that have to be in harmony with existing institutional ICT policies, library development policies, collection development policies and repository policies. Moreover, the institutions should provide financial support for increasing the bandwidth in their institutions. So, the study suggests that the existing staff should be re-trained to update their skills and knowledge on the promotion and marketing of library services through social media. Furthermore, it is recommended that the use of social media to market library resources and services should be promoted to increase library users' awareness of the kinds of social media their libraries use to support library services delivery.

\section{References}

Abok, V.A. \& Kwanya, T. (2014). Maximizing the potential of social media to deliver academic library services to students: a case study of the technical University of Kenya Library. Inkanyiso, Journal of Humanity and Social Sciences, 8(2), 147-155. 
Aina, L. O. (2002). Research in information science: An African perspective, University of Botswana.

Alphonce, S. \& Mwantimwa, K. (2019). Students' use of digital learning resources: diversity, motivations and challenges. Information and Learning Sciences, 120 (11/12), 758-772. https://doi.org/10.1108/ILS-06-2019-0048

Alkindi, S.S. \& Suqri, M.N. (2013). Social networking sites as marketing sites and outreach tools of library and information services. Global Journal of Human Social Science Arts, Humanities and Psychology, 13 (2), 26-28.

Babbie, E. (2011). The Basics of Social Research. Wadsworth.

Bosch, T. (2009). Using online social networking for teaching and learning: Facebook use at University of Cape Town. Communicatio: South African Journal for Communication Theory and Research, 35(2), 185-200.

Burkhardt, A. (2010). Social media: A guide for college and university libraries. College and Research Libraries News, 71(1), 10-24.

Chu, S. K. W. \& Du, H. (2013). Social networking tools for academic libraries. Journal of Librarianship and Information Science, 4(1), 64-75. https://www.org/doi:10.1016/j.jsams.2010.03.007.

Deng, S., Zhang, Y. \& Xu, J. (2016). Social media for librarians and users, a global perspective. American Library Association (ALA) Annual conference, Orlando, 26 June, 2016. https://stars.library.ucf.edu/ucfscholar/31/

Edewor, N., Okite, F., Osuchukwu, N. \& Egreajeana, D. (2016). Marketing library and information services in selected university libraries in Africa. International Journal Advanced Library and Information Science, 4 (1), 291-300.

Eligi, I.J. \& Mwantimwa (2017). ICT accessibility and usability to support learning of visually-impaired students in Tanzania. International Journal of Education and Development using ICT, 13(2), 87-102. https://www.learntechlib.org/p/180638/.

Ezeani, C.N. \& Igwesi, U. (2012). Using social media for dynamic library service delivery: the Nigeria experience. Library philosophy and practice (e-journal), No.814. http://digitalcommons.unl.edu/libphilprac/814

Hashim, K., Al-Sharqi, L. \& Kutbi, I. (2016). Perceptions of social media impact on social behavior of students: a comparison between arts and science faculty. Online Journal of Communication and Media Technologies, 6(4), 147-165. https://doi.org/10.29333/ojcmt/2574

Jain, P. (2013). Application of social media in marketing library and information services: a global perspective. European Journal of Business, Economics and Accountancy, 1(1), $1-13$

Jeremia, A. (2017). Librarians' knowledge and skills in marketing resources of selected academic libraries hybrid collections in Tanzania. MA. Dissertation, University of Dar es Salaam.

Kavulya, J.M. (2004). UniversitylibrariesinKenya:astudyoftheirpracticesandperformance: http://edoc.hu-berlin.de/dissertation/kavulya-joseph-muema-2004-0219/PDF/Kavulya.pdf.

Kim, K.S. \& Sin Sei-Ching, J. (2014). Social media as information sources: Use and evaluation of information from social media. Final report (2013) OCLC/ ALISE Library and information science research grant project.

Kiplagat, P. \& Ombiro, R.M. (2016). Social media usage and academic performance in secondary schools, Kenya. International Journal of Trend in Research and Development, 3 (6), 220-225.

Khan, S.A., \& Bhatti, R. (2012). Application of social media in marketing of library and information services: A case study from Pakistan. Webology, 9 (1). https://www.webology.org/2012/v9n1/a93.html 
Kong, E. W. S., Lam, P. F., Chiu, D. K. W. \& Ho, K. K.W. (2016). Applications of social media in academic library services: A case of the Hong Kong Polytechnic University library. International Journal of Systems and service oriented Engineering (IJSSOE), 6(2). 175-183

Landis, C. (2010). A social networking primer for librarians. Neal - Schuman Publishers, Inc.

Luo, L., Wang, Y. \& Han, L. (2013) Marketing via social media: a case study. Library HiTech, 31 (3), 455 - 466.

Lwoga, E.T. (2014). Integrating web 2.0 into an academic library in Tanzania. Journal of Electronic Library, 32 (2), 183-202.

Manda, P.A. (2005). Electronic resources in academic and research institutions in Tanzania. Information Development, 21 (4), 269-282. https://doi.org/10.1177/0266666905060070

Mollel, M. M. \& Mwantimwa, K. (2019).User attitude towards the utilization of e resources at the Institute of Finance Management. International Journal of Education and Development using Information and Communication Technology, 15 (4), 5-21

Mwantimwa, K. T. \& Nkhoma-Wamunza, A. (2016). Perception on adoption and application of Web 2.0 technologies in selected academic libraries in Tanzania. University of Dar es Salaam Journal, 11 (2), 17-30.

Mwantimwa, K., Elia, E. \& Sichwale, E.N. (2017). Utilizations of e- resources to support teaching and research in higher learning institutions in Tanzania. University of Dar es Salaam Journal, 12 (2), 98-123.

Mwantimwa, K., Mwabungulu, E. \& Kassim, M. (2021). Academic staff and researchers' use of electronic resources in Tanzania: a comparative study. International Journal of Education and Development using Information and Communication Technology (IJEDICT), 17 (2), 55-75.

Mwantimwa, K., Kassim, M., Mwabungulu, E. (2019). Enhancing reading culture among university learners in Tanzania: Policy Brief. Presented at the $2^{\text {nd }}$ Annual Conference on Research and Inclusive Development, Bridging the Gap: Connecting Research to Policy, 14th-15th November 2019. Organized by UDSM \& Funded by Sida.

Mundt, S. (2013). Evaluating the marketing success of libraries, social media presences. Retrieved from http://library.ifla.org.

Nachimias, C.F. \& Nachimias, D. (1996). Research methods in the social sciences. Word Press.

Nduka, S. C. (2015). Use of social media in marketing library and information services in Nigeria Libraries. Social Media Strategies for Dynamic Library Services Development. (E-journal). https://www.org/doi:10.4018/978-1-4666-7415-8.ch009

Noel, R. \& Waugh, T. (2002). Marketing library and information services comparing experiences at large institutions in putting knowledge to work. Papers Presented at the Special Libraries Association Conference (Los Angeles, California, June 9-12, 2002). https://eric.ed.gov/?id=ED478094 